シンポジウム「めまいの発症機序を考える」

\title{
不安障害／抑うつの関与
}

堀井 新

\section{Involvement of anxiety and depressive disorder}

\author{
Arata Horii \\ Department of Otolaryngology, Osaka University School of Medicine, Osaka
}

Based on our recent papers (Horii A et al. Otol Neurotol 2004, Horii A et al., J Vestibular Res 2007), we discussed the psychiatric involvement in patients with vertigo and dizziness. Seventy percent of patients with chronic dizziness showed a high score in the Hospital Anxiety and Depression Scale (HADS), suggesting that many dizzy patients have comorbid psychiatric disorders. Fluvoxamine, one of the selective serotonin reuptake inhibitors (SSRIs), administered at a dose of $200 \mathrm{mg}$ per day was effective for subjective handicaps due to dizziness in patients with or without neuro-otologic illnesses, owing to its actions on both the comorbid anxiety and depressive disorder. More aggressive psychiatric treatment, such as administration of higher doses, may be the next step of treatment for non-responders without neuro-otologic diseases, because these patients have been shown to suffer from more severe psychiatric illnesses. In contrast, other types of drugs that are known to help recovery of the vestibular function are recommended for neuro-otologic diseases in patients without clinically significant anxiety or depression and non-responders to fluvoxamine. The main causes of dizziness in patients without physical neuro-otologic findings were psychiatric disorders. Bidirectional relationships between vertigo/dizziness and psychiatric disorders could be explained by the anatomical connections between the brainstem and limbic system, including the amygdala.

\section{はじめに}

めまいを訴える患者では抑うつ神経症や不安神 経症を合併することが多い。このような病態は純 粋なうつ (depression) や不安障害 (anxiety disorder）と考えるより，ストレス下における一種 の適応障害として不安症状やうつ症状が出現して いるものと思われ, 両方同時に出現する事も多 い。少なくともめまいを主訴に耳鼻科を初診する 患者に, 純粋なうつ病や不安障害の一症状として

大阪大学大学院耳鼻咽喉科
めまいをきたしている症例は意外と少ない。本稿 では純粋なうつや不安障害による狭義の心因性め まいだけでなく，心因が器質的前庭障害へ悪影響 を与えめまいを増悪させているようなケースも含 め心因性めまいとして扱い, 主として我々のデー 夕 ${ }^{12)}$ から解説する。

精神科医から見ためまいと治療へのヒント

ペンシルバニア大学（現メイヨークリニック）

の精神科医 Staab はうつや不安障害など何らかの 精神疾患を持ち，慢性的なふらつきを訴える患者 の詳細な病歴（ふらつきの発症と精神疾患の発症 
とどちらが先であったかなど）を取り，さらに耳 鼻咽喉科医の Ruckenstein と共同で詳細な前庭機 能異常の有無を検討し, 精神疾患と前庭機能異常 の関連を以下のような分類した ${ }^{3)}$ 。

1. Psychogenic pattern: 狭義の心因性めま い, 精神疾患の 1 症状としてふらつきが生じ ている。

2. Otogenic pattern：前庭機能異常が先行し, その後精神疾患を発症している。

3. Interactive pattern : 元来あった精神疾患の 増悪が前庭機能異常を誘発している。

これら 3 パターンはほぼ $1 / 3$ づつの頻度で存 在したと報告している。この研究は精神科医から の報告であるため，全員が何らかの精神疾患を持 っている患者ばかりが対象であるが，別の見方を すると精神疾患をもつ患者でもふらつきを訴える 患者では, 約 $2 / 3 （ 2,3$ の otogenic pattern と interactive pattern) で前庭機能異常が見つか ったわけである。我々めまい患者を診る耳鼻咽喉 科医の立場から考えると, 上記の 3 つのパターン にプラスして，4．めまいを訴えるが精神疾患は 合併しない群，が当然加わることになる。我々耳 鼻咽喉科医はめまい患者を診るときに，この最後 の 4. めまいを訴えるが精神疾患は合併しない群 のみを, あるいは, 主として治療対象として考え てはいないだろうか？そしてこのことが以下に述 べるように，「所見のないめまい」や「一般の薬 物治療に抵抗性のめまい」の治療に難渋する原因 となっているのではないだろうか?

また, 当初 2 . otogenic pattern で発症したも のの, 器質疾患が回復しても精神疾患が残り今度 は 1 . psychogenic patternあるいは 3 . interactive pattern としてふらつきを訴える例もあると思わ れる。すなわち，

耳性めまい $\rightarrow$ 精神疾患 $\rightarrow$ 精神疾患に上るるら つき

精神疾患による耳性 めまいの誘発

となり, いわゆるめまいと精神疾患の間の悪循環 (vicious circle) におちいることになる。

耳鼻咽喉科医から見ためまい患者の精神症状 めまい患者におけるうつスコアー（Self-rating

\section{Depression Scale, SDS) と Hospital Anxiety and Depression Scale (HADS) : 予想通り高率 である}

前述のStaab らの報告とは逆に，耳鼻咽喉科を 受診するめまい患者の精神疾患の罹患率はどれほ どであるだろうか? 厳密には精神疾患の診断には 精神科医による診察が必須であるが，各種問診票 によるスコアーからの類推でもかなり正確に診断 できるし，我々臨床医にとってもいちいち精神科 を受診させる必要もなく便利である。例えば, SDS では48点以上で正常健人の平均＋標準偏差を超え るとされており，HADSでは12点を超えると精神 疾患罹病を診断する上で感度 $92 \%$, 特異度 $90 \%$ あることが報告されている゙)。以下述べる我々 の研究でもこれらのカットオフ值を用いた。荻野 らによるSDSアンケートを用いた検討による と，めまい患者414名中，42.5\%でうつ状態の合 併が判明した5)。Horii らによると大阪大学耳鼻咽 喉科めまい外来を受診した患者 47 名を連続して解 析した結果，SDSで高值（47>）を示した例は 18例 $(38 \%)$ で正常人と比べ有意に多く，めまい 患者の抑うつ傾向が高い事が分かった ${ }^{11}$ 。Horii ら によると, めまい患者のうち，何らかの前庭機能 異常が見つかる例は $50 \%$ であり, 同じめまい患者 において HADS が前述のカットオフ值を超えた 者は $72 \%$ とめまいを訴える患者にはうつや不安傾 向が高いことが判明した2)。

めまい診療で直面する問題点 :「所見のないめ まい」と「治療抵抗性のめまい」に精神疾患の関 与は無いか?

\section{所見のないめまい}

所見のないめまいは，1．軽微な前庭機能異常 が存在するが見落とされている例，あるいは 2 . 前庭機能は正常であるが，患者がめまいを訴える 例，に理論上分けられる。2 には狭義の心因性め まい, Staabの分類では Psychogenic pattern が当 てはまると考えられる。我々の検討では各種眼振 検査, 体平衡機能検査, 画像検査などで所見のな かっためまい患者の73\%で HADS が異常高值で あり，全体としてはSSRI 投与によりめまいの自 覚症状の改善とHADSの低下が見られた 方，SSRI 投与にも関わらずめまいの自覚症状の 改善のなかった群では改善群に比べ治療前の HADS が高い傾向にあり，かつ SSRI 投与によっ 
表 1

抗不安薬：速効性がある。ジアゼパム (セルシン), エチゾラム (デパス), ロフラゼプ酸エチ ル（メイラックス）など。

抗うつ薬：効果発現に時間がかかるが，スルピリド (ドグマチール) は比較的速効性がある。 3,4 環系と呼ばれる抗うつ薬は精神科 専門医の最後の薬物になっており, 我々 は手を出さない方が無難である。

SSRI：抗不安／抗うつ作用ともにある。速効性 はないが遅くとも 4 週間で効果発現があ る。女性では投与初期に吐き気が出やす い。我々はパロキセチン (パキシル) な ら $10 \mathrm{mg}$, フルボキサミン（ルボックス /デプロメール) なら $50 \mathrm{mg}$ で開始し， 1 週間でそれぞれ $20 \mathrm{mg}, 100 \mathrm{mg}$ に増量し 維持する。最初の 1 週間は吐き気が出や すい事を説明しメトクロプラミド（プリ ンペラン) を併用する。抗不安作用を強 く出したいときや，早く効かせたいとき はエチゾラム（デパス）やジアゼパム（セ ルシン）を併用する。

てもHADSが低下しなかった。このことは，所 見のないめまいのうち SSRI で治療効果の上がっ た群は狭義の心因性めまい 1 . psychogenic patternであり，無効であった群はより高度な精神疾 患を持った例であり，いずれにせよ狭義の心因性 めまいであると考えられる2)。

もちろん前庭機能異常の検索の精度は常に向上 させて行く必要があるが, 現在の大学病院レベル で行われている平衡機能検査で異常が見つからな い「所見のないめまい」は心因性めまいとして扱 い，精神疾患に対する治療を行うことで患者のめ まいに関する自覚症状を改善させうることが判明 した2)。

\section{治療抵抗性のめまい}

通常の治療では改善の見られないめまい疾患に 関して，例えば難治性のメニエール病であればゲ ンタマイシン鼓室内投与 ${ }^{6)}$, 内リンパ襄開放術 ${ }^{7)}$, 前庭神経切断術8) などが行われ，BPPVであれば 浮遊耳石置換法が行われるようになってきてい る。もちろんこのような耳疾患そのものに対する 新しい治療法の開発は最重要事項であるが，めま い疾患の難治化, 遷延化には精神疾患が関与して いることも予想される。

我々の検討ではメニエール病, 前庭神経炎, 遅
発性内リンパ水腫など明らかな末梢性めまい疾患 を持ち，慢性的なふらつきを訴える患者（罹病期 間平均19ケ月）をSSRIで 8 週間加療したとこ ろ，全体としてめまいに関する自覚症状の有意な 改善を認めだ2)。このように器質疾患を持ちめま いを訴える群でも70\%の症例では治療前の HADS が高值であり，2．otogenic pattern あるいは 3 . interactive patternの患者が多いことが判明し た2)。さらに，患者をSSRI 投与によりめまいの 自覚症状が改善した群としなかった群に分けて検 討すると，改善した群ではHADS も低下し，め まいが改善しなかった群ではHADS は不変であ った。めまいが改善しなかった群の治療前の HADS は「所見のないめまい」におけるSSRI 無 効例と異なり，低い傾向にあった2)。このことは， 器質的な疾患を持つめまい患者でも精神疾患がめ まいに悪影響を及ぼしており，SSRIによる精神 疾患の治療によりめまいの自覚症状が改善できる ことを証明するものである2)。

\section{心因性めまい（広義）の治療}

以上の結果から，純粋なうつや不安障害などの 精神疾患によるめまいだけでなく, 何らかの器質 疾患が判明している場合でも精神疾患の合併が疑 われる場合にはそれらに対する治療がめまいの自 覚症状の改善に有効であることが判明した。

SDS や HADS で患者が抑うつや不安神経症を 合併していると思われた場合はまず以下のような 説明を行った上で薬物投与を行う。

1.これらの精神疾患がめまいに悪影響を及ぼ す事

2. 重大な病気が隠れているわけではないので 安心する事

3. 過敏になった脳を安定させるのに抗不安薬 が良い事

4. 抗うつ薬や抗不安薬はうつや不安傾向の強 いめまい患者にすでに多く投与され効果が証 明されている事

5. 習慣性はコントロールできる事

6.一生服用する必要があるわけではない事

メニエール病等の器質疾患を持つ場合にはその 治療ももちろん並行して行う。もし表 1 のような 薬物療法を行っても有効でない場合，他の不定愁 訴に主訴がシフトしていった場合，自殺企図があ った場合等は精神科に紹介する。 


\section{めまい（末梢一中枢前庭系）と精神疾患（大脳 辺縁系) の解剖学的関連 :}

扁桃体と parabrachial nuclei (PBN) の関与

上記の事より，めまいを訴える患者にうつや不 安障害を合併する患者が多く存在し, それらの精 神疾患の治療がめまいの治療にも有用である事が 証明された。また，めまい疾患が精神疾患を続発 する事も証明されている。では，これらのめまい 疾患と精神疾患の相互関連性の基礎となる解剖学 的バックグラウンドは何であろうか?

めまいは主に 1 . 内耳末梢一前庭神経核一前庭 動眼 /前庭脊髄系の異常，2．小脳による前庭動 眼 /前庭脊髄系の制御の異常, 3 . 視覚 /固有知 覚系の入力異常により発症すると考えられる。頻 度的には動眼系や脊髄運動系, 小脳, 視覚/固有 知覚系の異常よりも, 内耳末梢の障害による前庭 神経核レベルでの入出力異常に起因するものが多 いと思われるので，めまい疾患の責任部位の代表 として前庭神経核を取り上げる事とする。一方, 精神疾患, 中でも不安障害は扁桃体の異常で発症 すると考えられている。扁桃体は大脳辺縁系に位 置し, 快/不快の判断や情動に関与し, SSRIの 不安障害に対する作用機序として扁桃体のセロト ニン神経系の活性化が考えられている。

めまいの中心である前庭神経核と不安障害の中 心である扁桃体を結びつける直接の経路は見つか っていないが, parabrachial nuclei (PBN) が中 継核として考えられている ${ }^{9)}$ 。トレーサーを用い た神経解剖学的研究で尾側 PBN から前庭神経核 への投射が確認され, 逆に前庭神経核から PBN への投射のある事も確認されている。前庭神経核 からの線維投射を受ける領域の PBN ニューロン が回転刺激や垂直方向の運動刺激で発火する事も 報告されている。また, 我々の報告でも, 動摇病 刺激で扁桃体中心核に FOS 陽性ニューロンが出 現する事が判明している ${ }^{10)}$ 。これらの解剖学的, 生理学的研究から前庭神経核と PBN の両方向性 の連絡が示唆される。PBN と不安障害の責任部 位と考えられる扁桃体中心核は相互に強い投射が ある事が報告されており，PBNを介して前庭情 報が扁桃体に入力し，逆に扁桃体で生じた不安や 情動に関する情報が前庭神経核の活動に影響を与 えるものと思われる。

中枢ノルアドレナリン神経系の細胞体の存在す
る青斑核から前庭神経核への投射が確認されてお り，この経路は前庭反射が覚醒度により影響を受 ける機序に関与していると考えられている。ま た，背側縫線核から前庭神経核へのセロトニン系 あるいは非セロトニン系の投射が前庭一PBN の 活動性を制御している可能性も報告されてい る9)。このような経路も高次中枢と脳幹前庭核レ ベルとの連絡に関与している可能性が考えられ る。

\section{最 後に}

めまいを訴える患者では高率に精神疾患を合併 しており，そのことがめまいの遷延化や難治化に つながっていると考えられる。器質疾患の有無に かかわらず，精神疾患の合併が疑われるときは積 極的にそれらに対する治療を行う必要がある。こ れらの背景は解剖学的にはPBNを介した前庭神 経核と扁桃体の相互連絡によって説明することが できる。

\section{文献}

1) Horii A, Mitani K, Kitahara T, et al: Paroxetine, a selective serotonin reuptake inhibitor (SSRI), reduces depressive symptoms and subjective handicaps in patients with dizziness. Otol Neurotol 25: 536-543, 2004

2 ) Horii A, Uno A, Kitahara T, et al: Effects of fluvoxamine on anxiety, depression, and subjective handicaps of dizzy patients with or without neuro-otologic diseases. J Vestibular Res 17: 1-8, 2007

3 ) Staab and Ruckenstein: Which comes first? Psychogenic dizziness versus otogenic anxiety. Laryngoscope 113: 1714-1718, 2003

4) Hosaka T, Awazu H, Aoki T, et al: Screening for adjustment disorders and major depression in otolaryngology patients using the Hospital Anxiety and Depression Scale. Int J Psych Clin Pract 3: 43-48, 1999

5 ）荻野 仁：心因性のめまい。武田憲昭編.耳 鼻咽喉科診療プラクティス $6 . \mathrm{EBM}$ に基 づくめまいの診断と治療. 60-63頁, 文光堂, 東京, 2001

6 ) Horii A, Saika T, Uno A, et al: Factors relating to the vertigo control and hearing changes following intratympanic gentamicin 
for intractable Meniere's disease. Otol Neurotol 27: 896-900, 2006

7 ) Kitahara T, Takeda N, Mishiro Y, et al: Effects of exposing the opened endolymphatic sac to large doses of steroids to treat intractable Meniere's disease. Ann Otol Rhinol Laryngol 110: 109-112, 2001

8 ）久保 武, 白石孝之, 西村将人, 他：めまい · 耳鳴に対する第 VIII神経切断術. Equilibrium Res 50: 209-214, 1991

9 ) Balaban CD.: Neural substrates linking bal- ance control and anxiety. Physiol Behav 77: 469-475, 2002

10) Nakagawa A, Uno A, Horii A, et al: Fos induction in the amygdala by vestibular information during hypergravity stimulation. Brain Res 986: 114-123, 2003

原 稿 到 着：平成20年 3 月 10 日

別刷請求先：堀井 新

于565-0871 大阪府吹田市山田丘2-2

大阪大学大学院耳鼻咽喉科 